\title{
The Expectation for Pension Insurance in Funded Schemes: Theoretical Model and Global Implementation
}

\author{
Ishay Wolf \\ Ono College, Tzahal St 104, \\ Kiryat Ono, Israel \\ Lorena Caridad y Lopez del Rio \\ Cordoba University, Av. de Medina Azahara, \\ 5, 14071 Córdoba, Spain
}

DOI: https://doi.org/10.36941/ajis-2021-0131

\begin{abstract}
In this study, we derive the financial position of pension actors in the market during pension system transition toward more funded capitalized scheme, mainly via an option benefit model. This is enabled by not considering the economy as a single earning cohort. We analytically demonstrate a socio-economic anomaly in funded pension system, which is in favor of high earning cohorts on the expense of low earning cohorts. This anomaly is realized by lack of insurance and exposure to financial and systemic risks. Furthermore, the anomaly might lead to pension re-reform back to unfunded scheme, mostly due to political pressure. We find that minimum pension guarantee is a rebalance mechanism to this anomaly, which increases the probability to sustainable pension scheme. Specifically, we argue that implementing the guarantee with an intragenerational, risk-sharing mechanism is the most efficient way to reduce the effect of this abnormality. Moreover, we exhibit the convergence process toward implementing minimum pension guarantee in many countries, which have capitalized their pension systems during the last three decades, particularly among Latin America and Central East Europe (CEE) countries.
\end{abstract}

Keywords: Defined Contribution (DC), Pay-As-You-Go (PAYG), Put Option, Social Security

\section{Introduction}

The global pension landscape is a continuously evolving one. Since the 199os, countries around the globe have introduced pension structural reforms, moving from the public pay-as-you-go (PAYG) defined benefit (DB) model to individual accounts in a multi-pillar architecture (Ebbinghaus, 2015). The main reason was and still is fiscal constriction, in terms of low fertility and longer period of retirement. Governments, particularly in aging Europe, could not meet anymore the obligations towards an adequate pension level in PAYG DB schemes, without raising taxes (Holzmann et al., 2008). This entailed diverting funds from the public pension system into individually funded accounts.

The financial market crash in 2008 challenged the merits of privately funded pensions, as their assets experienced a substantial decline within a short time (Grech, 2018; Altiparmakov, 2018). 
Consequently, over the last decades, the trust in the sustainability of the new pension pillar system has been shattered (Ebbinghaus, 2015; Sokhey, 2017). Nowadays, after the Covid-19 pandemic crisis and governmental bailout waves, one must wonder what the government's share in stabilizing the markets is. In addition, the public must re-consider the trust in the capability of financial markets to providing adequate benefits in old age (Wolf \& Caridad, 2021c).

Correspondently, vast literature have observed pressure toward reversals, and government insurance in countries, which have been through radical funded reform (Guardiancich, 2011; Orenstein, 2013; Altiparmalov, 2018; Naczyk and Domonkos, 2016). In particular, reversals and unstable pension systems have been recorded in CEE countries and South America (Mesa-Lago \& Valero, 2020; Grech, 2018). Over the last two decades, many other countries, developed and undeveloped, have conducted changes in their pension system and have defined once again the state as a central actor in the pension system. While the literature still studies the reasons for pension reversals some scholars argue that the unstable pension landscape is due to a lack of risk-sharing mechanisms in these countries compared to developed countries (Fultz and Hirose, 2019; Ebbinghaus, 2015; Grech, 2018).

In this theoretical framework, we offer an analytical explanation to one of the main motives in pension reversals, which is the implementation of minimum pension guarantee and increasing the weight of unfunded pillars (Orenstein, 2013). This composition contributes to this strand of literature regarding the proper balance between pension pillars structure and pension risks alleviation. Particularly, this paper offers a different perspective to examine pension schemes, using exchangeoption benefits and financial positions of the field's actor. This perspective enables us to consider inter-cohort financial position, in contrast to attributing the economy as a single unit. The option pricing theory and its appliances to pension systems' study enables this paper to be distinguished from the classic return/fertility consideration in conducting pension transition (Aaron, 1966), and contributing to existing literature of risks in pension schemes (Romaniuk, 2009; Chen et al, 2014). The novelty of this paper is its ability to offer an explanation of global pension evolution process by a simple option model and determine the minimum pension guarantee as an economic instrument and not only as a social one.

We show that during the transition toward funded pension scheme, the underlying asset that composes the pension benefit is being changed and includes financial and systemic risks. Likewise, the financial position of low earners, relative to high earning cohorts, is much worse. That consequence in lack of ability to hedge or diversify these risks compares to high earning cohorts. We claim that high earners 'buy' their superior financial position by a balance flow. The common balance flow is the implementation of minimum pension guarantee. Specifically, we point towards benefit guarantee, financed by intra-generational risk sharing, as the most efficient way to solve the anomaly in funded schemes. Lack of guarantee implementation might create system instability and political pressure, which leads to cyclical pension reforms. In the second part of this paper, we demonstrate these reforms in global experience of pension scheme evolution.

We show that most of the countries, which have made drastic privatization and capitalization reforms, have recently imposed risk-sharing instruments in the form of minimum pension guarantee. Furthermore, after a rigmarole of global experience and debates, implementation of minimum pension guarantee has become a key recommendation of global economic organizations as part of the funded modern scheme (Heneghan \& Orenstein, 2019). Particularly, we mention Chile's pension reform and reversal experience. Chile was a pioneer among more than 30 countries, which partly replaced their public pension systems with funded pension design (Guardiancich 2011; Orenstein 2013). Hence, the change in Chile signaled other countries to change their funded transition process in the future. The experience of Chile and most of the countries which made radical reforms in the $1980-90$ is correlated to this paper's argument regarding the need of insurance instrument of funded-capitalized scheme.

In the next section, we have characterized different pension systems by the financial instrument of options. By this model, we point towards a socio-economic anomaly in favor of high earning 
cohorts. In section 3, we suggest minimum pension guarantee as a re-balance instrument that might increase the probability to avoid cyclical pension reforms. We also investigate the guarantee-inoption perspective and define it as a 'collar' strategy. That definition helps us to understand its boundaries and constraints. In section 4, we turn to overview the implementation of minimum pension guarantee in funded pension schemes. We link this phenomenon to the anomaly above. Section 5 provides conclusion.

\section{The Financial Position Model}

The main difference between DB and DC pension schemes arises from the exposure to different types of risks, and how these risks are allocated among the employer, employee, plan sponsor, and the government (Rappaport \& Peterson, 2014). We introduce the actors' expectations and the balance point in the process of implementing a funded pension scheme.

\subsection{Different Pension Schemes}

Along the defined contribution plan, the pension's value is equal to the individual's accumulations at the time of retirement. The final amount of the funded capitalized pension fund can be expressed as function of the funded asset accumulations $\left(A_{T}\right)$ along the participant's career, during working phase, capitalized until death. $D C\left(T_{R}\right)=\tau A_{T}=\sum_{t=1}^{T_{R}-1} \tau w_{t} \prod_{t=1}^{T_{D}-1}\left(1+r_{t}\right)(1 a)$

Here $r_{t}$ is the average rate of return earned by the defined contribution (DC) plan on its portfolio of financial assets at time $t . T_{R}$ is the participant's retirement year, $\mathrm{t}=1$ is the time of enrolment in the pension fund and $T$ is the expected individual's lifetime as in this model, we avoid actuarial factors related to probabilities of survival. We define $w_{t}$ as the gross earnings equivalent at the beginning of each year.

The defined benefit (DB) scheme, however, is the function of the participant's wage, working period and age. The individual member is paid at the level of the fund obligations independently from market (asset) performance. Hence, intuitively: $D B\left(T_{R}\right)=\tau L_{T}\left(T_{R}\right)(1 b)$

Here, $L_{T}$ is the fund's liabilities and. Notably, $C_{L}$ and $P_{L}$ denote the call and put exchange options, respectively, whose payoffs at retirement are as follows: $C_{T_{R}}=\max (\tau A(T)-L(T), 0)(2 a)$, $P_{T_{R}}=\max (L(T)-\tau A(T), 0)(2 b)$

The European put option on the fund assets includes liabilities as the strike price and a maturity corresponding to the retirement date. The put-call parity in future terms is defined as follows: $C_{T_{R}}-P_{T_{R}}=\tau A(T)-L(T)(3)$

Hence, one can describe the DB scheme as: $D B(T)=L(T)=\tau A(T)+\left(P_{T_{R}}-C_{T_{R}}\right)(4)$

The investment in a defined benefit scheme, thus, can be replicated by a position composed of three elements: long position in the fund assets, $A$, long put position, $P_{L}$, and a short call position, $C_{L}$, at the same strike price. Systematically, defined contribution's benefits equal to investment in a defined benefit fund, buying call option $C_{L}$ and selling put option, $P_{L}$, at the same strike price.

$$
D C(T)=D B+\left(C_{T_{R}}-P_{T_{R}}\right)(5)
$$

\subsection{The Government}

The government is a mediator among different participants' generations and different field actors in the pension market. It is capable of bridging among commitments and payments through the distributional mechanism of public debt and tax. Naturally, like other actors in the field, the government wishes to decrease its fiscal obligations and future fiscal risks (Wolf \& Caridad, 2021b). It avoids prejudicing its other expenditure $(G)$ by its intervention in the pension market. Consequently, the government consistently tries to shift the pension market to a funded design and minimize benefits of social security, as it creates an intergenerational fiscal exposure. 


\subsection{The Society}

Society is a unification of individuals with a larger perspective than the lone individual. It is capable of intensifying the individual's expectations, creating political pressure on the government to consider the individual interests. In addition, it has a larger perspective, considering both old and retired persons and contributors during the working phase.

The society considers shifting to a mixed pension scheme with 2 pillars: social security and funded pillar with individual accounts. We define $\tau$ as the total contribution rate from the participant's wage. We split the contribution into two components: $\gamma$ as the portion of funded DC from the pension contributions and $(1-\gamma)$ as the contribution share, which finances the DB PAYG. The benchmark is the former DB PAYG pension scheme or a satisfying relationship between the individual's wage and his old age benefit.

The two forms of social security are detailed in equation (6): $L(T)=\sum_{i=1}^{N} \sum_{t=1}^{T} \tau w_{i, t}(1+g)^{t-1} *$ $R R(6 a), L^{\prime}(T)=\sum_{i=1}^{N} \sum_{t=1}^{T} \tau(1-\gamma) w_{i, t}(1+g)^{t-1}(1+n)^{t-1}(6 b)$

Here, $L(T)$, represents the former social security liabilities to participants and $L^{\prime}(T)$ the liability after the transition to a mixed pension scheme. $w_{i, t}$ is the individual wage of participant $\mathrm{i}$ (out of $n$ ) in time t. $g$ is the GDP per capita growth rate. Here, $R R$ is the average replacement rate of the former DB pension scheme. Society will shift to a funded pension fund if the participants' position in the funded scheme is better than the current intergenerational risk-sharing mechanism of social security. Since that mechanism is financed by the net government expenditure, if the improvement in society's financial position in the funded scheme is more than the government's negative flow, the total market position is improved, and the funded scheme is preferred.

The pension system is constructed from the mixed pillars of social security and funded fund.

The change in the society's position is: $\Delta$ (Pension Position $)=\tau \gamma \sum_{i=1}^{N} \sum_{t=1}^{T_{R}} w_{i, t}(1+r)^{t-1}+$ $L^{\prime(T)}-L(T)(7)$

At the macro-economic level, the government's net flow of old-age social transfers to the public can be described thus: $\Delta$ (Gov. Net Flow) = Expenditures - Revenues (8)

- The change in the government's revenues from the transition is: $-\gamma \tau \sum_{i,}^{n+1} w_{t+1}$

The change in the government's expenditures from the transition is: $L^{\prime}(T)-L(T)$

Hence, if the contribution rate is constant during the transition, one can determine that:

$\Delta($ Gov. Net Flow $)=L^{\prime}(T)-L(T)+\gamma \tau \sum_{i=1}^{N_{+1}} \sum_{T_{R}}^{T} w_{i, t+1}$ (9)

From (2) and (4), we plot that the intergenerational condition is: $\sum_{i=1}^{T}(1+r)^{t-1} \geq \sum_{i=1}^{T}(1+$ $n)^{t-1}(1+g)^{t-1}(10)$

According to (10), the share of the funded pillar in the total benefits is not significant. As long as the market yield is higher than the GDP per capita, it is worth implementing a funded or a mixed pension scheme.

Equation (10) represents the rationale of pension transitions from the economy level and is similar to Aaron's (1966) condition considering transitioning to funded scheme from PAYG $(r>n)$. According to the analysis above, the rule is true also for the transition to a mix/hybrid scheme as the condition does not depend on pension pillars' contribution rates.

\subsection{The Individual}

The individual expects to retain their standard of living in old age in any pension scheme and to avoid poverty (Kuitto \& Kuivalainen, 2020). The condition in (10) is valid on average or in the case of equal income distribution, which makes it relevant for society and not for the individual. In reality, the distribution is not equal. As income inequality level is higher, the probability for low earners to be financially worse off increases because of their option position characters. In that case, consistent with the late evolutions, political pressure of sub-groups may arise toward pension reversal (Wolf \& Caridad, 2021a, 2021b; Mabbett, 2020). The individual benefits from the transition if: 
$\tau \gamma A\left(T_{R}\right)+L^{\prime}\left(T_{R}\right)-\left(\tau A\left(T_{R}\right)+P_{T_{R}}-C_{T_{R}}\right)>0$ (11)

By reducing the total population indexation, one can determine that on average, the individual participant gains from the transition if the following is valid: $\tau(1-\gamma) w_{i, t}\left\{\left(1+g_{t}\right)^{t-1}\left(1+n_{t}\right)^{t-1}-\right.$ $\left.\left(1+r_{t}\right)^{t-1}\right\}+C_{T_{R}}-P_{T_{R}}>0$ (12)

If (5) is valid, the phrase in the large brackets is negative, but should be close to zero as in the long-term: $\left(1+r_{t}\right)^{t-1}=\left(1+g_{t}\right)^{t-1}\left(1+n_{t}\right)^{t-1}$. Consequently, one can determine that the individual expects to benefit from the transition if the minimum term is valid: $C_{T_{R}}-P_{T_{R}}>0$ (13)

All participants share the same financial position at the retirement of long call + short put. However, some have 'in the money' long call and 'out of the money' short put, and on the other pole, some have 'out of the money' long call and 'in the money' short put. As the participant's old-age benefit is higher, their position improves relative to the others. Put differently, one may assume that high earning cohorts might benefit from the funded scheme, as the cap ('RR') to their old age benefits is canceled. For other earning cohorts, old-age benefit insurance is much more essential, as they might fall into poverty if yields are insufficient. . It can be determined that the pension transition is biased in favor of high earners, compared to low earners. The extent of the bias depends on the dispersion of benefits above and beneath the former strike price. As the individual's accumulation is lower, his financial position from the transition is worse, and vice versa.

Hence, the question if the individual gains from the transition depends both on his wage level along his career and the market yield. If the individual's wage is relatively low, in order to gain from the transition, he must be exposed to market risk extensively.

Although the compensation to market risk provides an expected higher yield than the GDP per capita, risk avert participants might avoid high exposure to market fluctuations. That tendency is crucial when the individuals' accumulations are not high. Using simulations of the utility function, Wolf and Ocerin (2021) found that low-earning cohorts wish to avoid extensive exposure to market risk in their old age benefits.

\subsection{Pension Sustainability}

The current study points out a clear fiscal interest pushing toward the funded-capitalized transition. If the average market's yield is high enough, according to condition in (10), there is a chance of actual transition. However, the sustainability of the transition depends on the political pressure. In case most of the people benefit from the transition, according to the condition described in (12), the new system can be sustainable. Alternatively, if critical mass of participants are worse off the transition, a political pressure might emerge toward pension reversals (Grech, 2018; Orenstein, 2013; Ebbinghaus, 2019). Here, we mention the re-reforms pension wave in the last two decades back toward PAYG scheme mainly in CEE and Latin American countries. Examples of these processes are given in the second part of this composition.

Trying to reduce the probability to pension reversal, the government has an incentive to increase pension accumulations to the low tail of accumulation distribution. The more the people benefit from the transition, the higher the probability of keeping the transition sustainable (Zaidi, 2010). To this consideration, we add public social targets of poverty alleviation and income redistribution. In reality, the government as a central planner and mediator enables financial transactions by implementing minimum pension guarantee (some call it the "Zero Pillar").

As explained above, as the participant's benefit is lower, their financial position or risk burden will worsen. To meet an equilibrium, those participants who benefit from the transition compensate those who lost.

The compensation or the reverse flow must be made during the working phase when low earners still have political power. If they wait for the compensation during retirement, their financial security will be in the hands of high earners or another generation. A put option to be sell by high earning cohorts to low earners during the working phase will balance the market, as it promises flows 
from side to side when exercised during retirement. The actual exercising of the option is a risksharing mechanism, which may include tax, social security benefits, and means-tested. We will define this option as a minimum pension guarantee $(\mathrm{mpg})$.

\subsection{The Guarantee Boundaries}

Obviously, finding the minimum effective strike price is challenging as it depends on a variety of parameters. Due to social concerns, some countries may mark the poverty line as a floor that ensures proper standard of living in old age (Grande \& Visco, 2010; Pennachi, 2009). The poverty line might be high enough to keep the transition sustainable, but it also depends in other variables that change from time to time, such as the dispersion level and the market's yield.

The model presented above allows us to imply further characteristics of the minimum pension guarantee mechanism. We attribute to the guarantee as a long put option on behalf of the individual. By holding this position, the lower pension accumulation the higher the insurance effect. Consequently, the guarantee's cost is simply the discounted value of benefits from the option, discounting at the government's risk-free rate (Grande \& Visco, 2010). The guarantee follows two conditions of a floor and a ceiling.

\subsubsection{The Guarantee Floor:}

The bottom boundary is in fact a political condition. Economically, the target of the guarantee is to differentiate the individual from their peer group and reduce the motivation to unite, creating political pressure. Let us define $\beta^{l}\left(\beta^{l}<N\right)$ as the critical mass of participants, during the working phase, who have combined political power to influence the pension design. Hence, during the early stage of the working phase, the guarantee must improve the financial position of $\beta^{l}$ by financing from $\beta^{h}$ participants.

The old-age guarantee during the working phase, which ensures a certain cushion, is a put option with a strike price equal to the guarantee level. $\sum_{n=1}^{N} p u t(m p g)>p \cdot v\left(\sum_{t=T_{R}}^{T} \sum_{n=1}^{\beta^{l}} w_{i . t}[R R-\right.$ $\left.\left.B_{n, T_{R}}^{f}\right]^{+}\right)$

\subsubsection{The Guarantee Cap:}

The first constraint determines that $m p g<$ 'RR'. At the edge case, when the guarantee line is at the former average level, ' $R R^{\prime}$, the pension system is practically back to the DB pension scheme. Hence, it is assumed that the guarantee's exercise price cannot pass that line. Furthermore, in all cases, in order to avoid a situation where the guarantee overlaps the funded pillar and causes an anomaly in the pension system, the guarantee must not be index higher than the GDP per capita (see also Smetters, 2002).

More specifically, the upper boundary of the guarantee cost is dictated by the constraints of those who finance it. The central planner must ensure that those who finance the guarantee still benefit from the transition. This constraint can be described as: $p \cdot v\left(\sum_{t=T_{R}}^{T} \sum_{n=1}^{\beta^{h}} w_{i, t}\left[B_{n, T_{R}}^{f}-R R\right]^{+}\right)+$ risk p. $>\sum_{n=1}^{N}$ put $(m p g, \sigma)(15)$

In financing the guarantee, the high earners give up a certain share of their pension returns. This situation is analogous to selling a call option. Consequently, the value of the guarantee at time o is equal to the call option value. $\sum_{n=1}^{N}$ put $(m p g, \sigma)=\sum_{n=1}^{N} \operatorname{call}\left(\beta^{h}, k^{*}\right)$ (16)

The underlying asset changes from wage level to total pension accumulations from both pillars. Consequently, we argue that any insurance must be examined related to the overall benefits and in absolute terms.

The larger the group which finances the guarantee, the smaller the financial burden on the 
individual's shoulders. Assuming certain income inequality level, the risk premium is realized by the difference between the new strike price, $k^{*}$ and the former one, 'RR', where, $k^{*}>^{\prime} R R^{\prime}>m p g$. The option's strike price depends on the income distribution. As participants benefit from the funded scheme in the high part of the income distribution, the call option's strike price can be higher.

The economy as a whole "pays" the price for the income inequality level: the higher the inequality level, the higher the guarantee cost. In high-income inequality level, $\beta^{l}$ is higher and the option prices are higher, where, it will be difficult to find a satisfying guarantee, as its implementation will be quite expensive.

Another factor influences on the guarantee cost is the standard deviation of pension accumulation. Following Black-Scholes option pricing model, higher pension portfolio's volatility increases the guarantee cost. Hence, the "financial" position of the state, as the writer of the option, is in more stress. This is in line with Barr and Diamond (2009), who argued against the pension literature strand during the 1990s, which pushed to implement funded pension funds to decrease fiscal burdens.

\subsection{The Guarantee Finance}

The guarantee can be financed across a variety of mix possibilities between two different risk-sharing poles:

\subsubsection{Intra-generational risk sharing}

Intra-generational risk sharing is beneficial to redistribution mechanism among the same earning cohort in parallel to the existence of pension pillars. Through this method, the central planner avoids financial burdens on other generations in the form of increasing contributions. If the transition creates an anomaly that favors high earners at the expense of low earners, the most obvious way to finance the guarantee is by intra-generational risk sharing with an opposite financial flow than the transition. That particular way of finance is interpreted as a compensation to low-earning cohorts from those who benefit from the transition. In other words, high earners finance the guarantee by selling some of their upside benefits and creates a position of long put + short call (Feldstein and Ranguelova, 2001a; Smetters, 2002).

\subsubsection{Inter-generational risk sharing}

The guarantee can be financed from working cohorts' contributions in a PAYG or a tax scheme. However, this way of financing entails three major restrictions. First, if the central planner chooses to increase contribution rate, $\tau$, low earners absorb a share of the finance burden to correct the anomaly that discriminates against them. Hence, the anomaly discussed above which is in favor of high earners could not be solved completely. Second, the contribution rate in mix-pension system is not suitable for low earners but is optimal for high earners (Wolf and Caridad y Ocerin, 2021). Hence, increasing the contribution rate might substitute one socio-economic anomaly in another. The third constraints stems from government intervention. Risk sharing among generations requires government intermediation and hence exposure to fiscal risks. If the guarantee is financed completely from unfunded pillar's contributions, there is a pure intergenerational risk sharing. If the government participates in the financing guarantee on the expense of other public or social expenses $(\mathrm{G})$, there is a mix of inter- and intra-generational risk-sharing mechanism in financing the guarantee.

Besides, the total participation budget cannot pass the former fiscal expenses before the transition as this cost is one of the main motives to the transition in the first place (Holzmann \& Hinz, 2005). According to the model above, this cap is summed to $\tau L^{\prime}(T)-L(T)$ in future value terms. In order to control social budget expenses, one should check eligibility rules for other 
programs and reduce the automatic passport to implement other programs.

A combination of risk-sharing mechanisms to implement the guarantee can be used to increase, to an extent, the unfunded contribution rate, redirecting fiscal expenses and differentiation in social security benefits among earning cohorts. Table 1 summarizes the guarantee finance principles.

Table 2: Risk sharing methods to finance minimum pension guarantee

\begin{tabular}{|c|c|c|}
\hline Risk-Sharing & Solution of Finance & Constraints \\
\hline $\begin{array}{l}\text { Intra-generational risk } \\
\text { sharing }\end{array}$ & $\begin{array}{l}\text { - selling some of the upside potential returnsi of the funded } \\
\text { pension fund } \\
\text { - On the expense on social programs or means-tested to retires }\end{array}$ & $\begin{array}{l}\text { - Guarantee cap - RR level } \\
\text { - Indexed < GDP per capita }\end{array}$ \\
\hline $\begin{array}{l}\text { Intergenerational risk } \\
\text { sharing }\end{array}$ & $\begin{array}{l}\text { - Increasing social security contributions } \\
\text { - On the expense on public programs fiscal costs }\end{array}$ & $\begin{array}{l}\text { - Guarantee cap - RR level } \\
\text { - Un optimal contribution rate for low } \\
\text { earners } \\
\text { - Fiscal Cost }<\tau L^{\prime}(T)-L(T) \\
\text { - Indexed }<\text { GDP per capita }\end{array}$ \\
\hline
\end{tabular}

\section{The Demand for Pension Guarantee in Funded Pension Schemes}

\subsection{Global Perspective}

In this section, we argue that the insurance expectation theory, introduced above, can explain some of the cyclical pension reforms across the globe in funded pension designs. Particularly, we attribute to the minimum pension guarantee as a major motive in these reforms (Boado-Penas et al. (2019)).

After Chile's funded reform in 1981, between the mid-199os and early 2000s, 37 countries, predominantly in Central and Eastern Europe (CEE) and in Latin America, reformed in some level their pension systems with a funded pillar (Naczyk and Domonkos, 2015). This portion includes 6 OECD countries members, which are marked as 'FDC' pension systems, or countries with dominant funded pillar (OECD, 2019). Additionally, 2 countries privatized their public pension system in Africa: Nigeria (2004) and Ghana (2010). The majority of countries in the world have opted not to privatize (Ortiz et al, 2018; Fultz \& Hirose, 2019).

Years after completing their first reform, 19 of the countries that made radical pension reforms have conducted a reversal in their pension design in various levels, rolling back to PAYG scheme with intense public pillar (Natali, 2018; Ebbinghaus, 2019). Other countries have preserved their pension system but have strengthened the guarantee pillar and the safety nets (Turner and Rajnes, 2009). Table 3 reports this trend around the globe and the appendix details by global region and country.

We count 15 CEE countries which implemented during the 1990s and early 2000 s fundedcapitalized pension pillar: Hungary and Kazakhstan (1998), Croatia and Poland (1999), Latvia (2001), Bulgaria, Estonia and the Russian Federation (2002), Lithuania and Romania (2004), Slovakia (2005), Macedonia (2006), Czech Republic (2013) and Armenia (2014). All countries but Armenia and Kosovo reversed their pension system to more government intervention and dominant PAYG public pillar and strengthened their safety nets.

Among 14 Latin America countries that have been through extensive pension reform, we recognize eleven countries that have withdrawn to a dominant public pillar or have been implementing significant safety net to retired, or both. These countries include Argentina, Colombia, Uruguay, Bolivia, Mexico, Venezuela, El Salvador, Nicaragua, Costa Rica and Ecuador. In Peru, the debate on pension reversals is continuing (Ortiz et al., 2018). There have been no major reforms in the Dominican Republic and Panama.

The OECD (2019) considers in its reports another six countries to implement funded pension

\footnotetext{
${ }^{1}$ See Feldstein and Ranguelova, 2001a; Smetters, 2002
} 
scheme. According to the appendix, four of them, Australia, Denmark, Norway and Sweden, implement strong redistribution mechanism and keep strengthening it as part of their socioeconomic policy (Nelson et al. 2019). According to the Mercer report (2018), these countries have the strongest and the most sustainable pension systems across the world. Another country, Italy, implemented a mix of NDC and small funded pension scheme with low poverty rate of the elderly (Franco \& Tommasino, 2020). The last country, Israel, has not implemented yet any major redistribution mechanism. The reason might be that only small group has retired from the last reform in 1995 and the market returns are quite high so far (OECD, 2019).

Table 2:

\begin{tabular}{|l|c|c|c|c|c|}
\hline \multicolumn{7}{|c|}{ The Cyclical Pension Reforms } \\
\hline & CEE & $\begin{array}{c}\text { Latin } \\
\text { America }\end{array}$ & $\begin{array}{c}\text { Other OECD } \\
\text { Countries }\end{array}$ & Africa & Total \\
\hline \multicolumn{1}{|c|}{ Total Funded scheme } & $\mathbf{1 5}$ & $\mathbf{1 4}$ & $\mathbf{6}$ & $\mathbf{2}$ & $\mathbf{3 7}$ \\
\hline $\begin{array}{l}\text { Rolled Back to Dominant Public Pillar + } \\
\text { Implementing Minimum Pension Guarantee }\end{array}$ & 13 & 6 & & & 19 \\
\hline $\begin{array}{l}\text { Preserving Pension Scheme + Strengthening } \\
\text { Guarantee and Saftey Nets }\end{array}$ & & 5 & 4 & & 9 \\
\hline Keeping Pension Scheme & 2 & 3 & 2 & 2 & 9 \\
\hline
\end{tabular}

Source: Authors' elaboration based on OECD, 2019; Fultz and Hirose, 2019; Ortiz et al, 2018.

At first, some critics, including the World Bank, have called this type of reform short sighted, and assert that it eases pension finance now at the cost of jeopardizing it in the future (the presumed Aaron (1966) condition). However, as shown by above model, this argument applies only as long as the second pillar's investment returns are favorable, that is, exceed the growth rate of GDP.2 This condition does not apply to all countries all the time. Some Latin America and CEE countries' second-pillar rates of return have been chronically low and often negative (Altiparmakov, 2018; Borzutzky and Hyde, 2016). Anyway, the literature does not solely attribute the pension reforms and evolution to the market yields. Some scholars link CEE countries' reversals with fiscal stress after the financial crisis (Gora, 2016) and the need to comply with the Maastricht rules (Kay, 2014). Mesa-Lago and Valero (2020) links the Latin America countries reversals to inadequate benefits and high transition costs. According to Altiparmakov (2018), other reasons might include low coverage and disappointment from capitalized rates of returns. According to the above literature and the motives in designing pension schemes after pension reforms, a key reason for the reversal trend in CEE and Latin America countries is the political pressure stemmed from unfulfilled insurance expectations and inadequate benefits (Natali, 2018).

\subsection{Focus on the Chilean Pension Evolution}

Chile's pension system is among the five countries in Latin America, which preserved its pension system but imposed greater weight in the guarantee pillar. Vast literature and documentation of global economic organizations describe the cyclical pension process of pension system in Chile as a global representative case (Fajnzylber, 2019; Mesa-Lago and Bertranou, 2016; Barr and Diamond, 2016; Borzutsky and Hyde, 2016).

In 1981, Chile was the first country to reform its public DB pension scheme with a funded scheme pillar. Prior to 2008, the PASIS program was targeted to low earners with no accumulations,

${ }^{2}$ GDP growth is assumed to be a proxy for wage growth. 
providing a sub-poverty benefit (as of 2008, US\$110 per month - 75\% of the minimum wage) and subject to budget availability (Fajnzylber, 2019. P.6).

Following the disappointment from privatization reform, in 2008, Chile enacted a new comprehensive pension reform, introducing the NSP pillar. This mechanism tries to balance the tension between extending universal coverage while maintaining an affordable fiscal cost. This pillar is financed by the general revenues and on the expense of social security benefits to high earning cohorts, which is a mix of inter and intra-generational risk sharing mechanism.

In six years, the coverage rose significantly: labor coverage rose by two percentage points, elderly coverage rose by five percentage points, disability coverage rose points and the number of beneficiaries in the period 2014-2018 doubled, reaching 1.24 million. In addition, poverty reduced by 2.7 percentage points (Fajnzylber, 2019). Chile's 2008 reform improved the chances that future lower income retirees might have higher old age benefits without increasing the government deficit (Barrientos, 2018).

Related to the theory described in the first part, we mark two reasons for the pension reversals in Chile. The first is the economic principle of pension transition above (19). The transition to capitalized scheme was questionable in the first place due to low returns and sub-optimal performances (Acuña \& Iglesias, 2001). This instigated political pressure to re-reform the pension scheme to more intensive role of the state (Kay, 2014). The second reason is low accessibility to redistribution mechanisms in the funded scheme, which push to low coverage (Borzutzky and Hyde, 2016). Political pressure toward pension reversal was due to the lack of insurance, with risks, shifted from the government to the public.

\section{Discussion}

According to the theoretical model, government intervention in the form of an unfunded pillar or minimum pension guarantee is needed to increase the sustainability of pension reform. It might seem odd, prima facie, as the government tries to minimize expenses in the first place. The question boils down eventually to the premium level the government is willing to pay to increase the sustainability of the funded pension system. Diversifying risks levied on participants in the form of some weight for social security and minimum pension guarantee can create an equilibrium, where fiscal expenses will be reduced and a substantial share of the population will benefit in relation to the previous pension scheme.

As there are different reasons for the pension evolution in each country, the global experience confirms the demand for redistribution mechanisms or minimum pension guarantee as common motives in the late design of pension reforms around the globe. These mechanisms can address the form of pension top-ups like in Argentina and Poland, or for instance a zero pillar like in Chile, Hungary and Kazakhstan.

Implementing pension guarantee signals the low earning cohorts to trust the pension system at retirement despite the various risks burden. From another perspective, the pension guarantee can be identified as a non-formal 'agreement' between low earners and high earners. On one hand, by the transition, participants are exposed extensively to financial risks compares the former pension system. High earning participants gain from the reform, as there is no cap to their benefits in old age and they can manage financial risks and hedge them by wider pension portfolios. On the other hand, high-earning cohorts ensure low-earning cohorts' pension benefits adequacy.

\section{Conclusion}

In line with Barr and Diamond (2006), we argue that the considerations' validity of pension transition as function of aging and return is limited. Using a simple option exchange benefit model, we demonstrate that the transition is beneficial, mainly for high earning cohorts on the expense of low earning cohorts. Moreover, as a complement to the emerging literature stranded on pension reforms 
and re-reforms, we claim that in funded pension scheme, the central planner has an incentive to implement minimum pension guarantee, avoiding cyclical pension reforms and fiscal risks while leaning on unfunded pillars.

The intra-generational equilibrium includes implementing a put option with clear boundaries of the strike price. This option has dual characteristics for the writers and the buyers that make it an obligatory tool for equilibrium. While from one angle, it compensates for excessive market risk and provides insurance, from the other, it alleviates political rejection of funded pension design. The option's strike price divides the population that might have been affected adversely by the transition and improves the financial position of some of the groups. Thereby, the political power of individuals who reject the funded design decreases.

The theory above enables to explain the cyclical process of pension reforms in many countries, which have performed radical pension reforms in the last 30 years. We find that the common characteristic of many pension reversals is the implementation of minimum pension guarantee in a public PAYG pillar. The Chilean experience strengths the claim that poverty prevention pillars and public guarantees are a fundamental part of any modern pension system that include dominant funded pillar (Fajnzylber, 2019).

We find this study highly relevant in the current times when governments seek exit strategies from the Corona-virus pandemic-related financial crisis. Policymakers are moving somewhat beyond the narrow interpretation of pension system sustainability adopted in the previous decades. The link between the financial position of individuals and political pressure might be a novelty in the existing literature but has been proven true in the case of pension reversals in CEE countries and Latin America. Countries which implement funded pension schemes must ensure periodically that pension guarantee schemes are adequate and consistent with the income distribution level. Additionally, as financial and systemic shocks are accelerating public reaction, it will be interesting to examine the pension system design sometime after the corona-virus crisis.

\section{References}

Aaron, H., (1966), “The Social Insurance Paradox”, Canadian Journal of Economics and Political Science, Volume 32, Issue3.

Acuña, R., \& Iglesias, A. (2001). Chile's pension reform after 20 years. Working paper o129. Washington, DC: The World Bank.

Altiparmakov, N., (2018), "Another look at causes and consequences of pension privatization reform reversals in Eastern Europe”, Journal of European Social Policy, Volume 28, Issue 3, pp. 224-241.

Barr, N., Diamond, P., (2009), "Reforming pensions: Principles, analytical errors and policy directions", International Social Security Review, Volume 62, Issue 2, pp.5-29.

Barr, N., Diamond, P., (2016), "Reforming Pension in Chile“, Polityka Społeczna, Social Policy No 1 ENG/2016, p.4-8.

Barrientos, A., (2018), "Pension Reform in Latin America", Routledge, https://doi.org/10.4324/9780429447389

Borzutzky, S., Hyde, M., (2016),"Chile's private pension system at 35: impact and lessons", Journal of International and Comparative Social Policy, 32:1, 57-73, DOI: 10.108o/21699763.2016.1148623

Chen, D., Beetsma, R., Ponds, E., \& Romp, W. (2014). "Intergenerational Risk-Sharing Through Funded Pensions and Public Debt". Journal of Pension Economics and Finance, 15(2): 127-159. https://doi.org/10.1017/S1474747214000365

Datz, G., Dancsi, K., (2013), "The politics of pension reform reversal: a comparative analysis of Hungary and Argentina", East European Politics, 29:1, 83-10o, http://doi.10.108o/21599165.2012.759940

Feldstein, M., \& Ranguelova, E. (2001). Individual Risk in an Investment-Based Social Security System. The American Economic Review, 91(4), 1116-1125.

Fajnzylber , E., (2019), “Chile’s Solidarity Pillar: A Benchmark for Adjoining a Zero Pillar with Defined Contribution Schemes in 'Progress and Challenges of Nonfinancial Defined Contribution Pension Schemes": Volume 1. Addressing Marginalization, Polarization, and the Labor Market. October 2019, 241-258

Franco, D. \& Tommasino, P. (2020). Lessons From Italy: A Good Pension System Needs an Effective Broader Social Policy Framework. Intereconomics 55: 73-81. https://doi.org/10.1007/s10272-020-0874-4 
Fultz, E. \& Hirose, K. (2019). "Second-Pillar Pensions in Central and Eastern Europe: Payment Constraints and Exit Options". International Social Security Review. 72 (2): 3-22. https://doi.org/10.1111/issr.12201

Giorno, C., Jacques, A., (2016), "Improving the Pension System and the Welfare of Retirees in Israel", OECD, Working Paper No.1288, OECD Publishing, Paris.

Gora, J., (2016). "Evolution of supplementary old-age pension systems in selected CEE countries". Journal of Management and Finance. 14(4). 169-162.

Guardiancich, I., (2011), "Pan-European pension funds: Current situation and future prospects", International Social Security Review, Volume 64, Issue 1, pp. 15-36.

Grande, G., Visco, I., (2010), “A Public Guarantee of a Minimum Return to Defined Contribution Pension Scheme Members", The Journal of Risk, Vol 13, Issue 3, PP.3-43.

Grech, A., (2018). "What Makes Pension Reforms Sustainable?" Sustainability. 2018. 10(8). https://doi.org/10.3390/su10o82891

Heneghan, M. \& Orenstein, M. (2019). Organizing for impact: International organizations and global pension policy. Global Social Policy, 19(2), https://doi.org/10.1177/1468018119834730

Holzmann, R., (2013), "Global pension systems and their reform: Worldwide drivers, trends and challenges", International Social Security Review, Volume 66, Issue 2, pp.1-29.

Holzmann, R., Hinz, R., (2005), “Old-Age Income Support in the 21st Century: An International Perspective on Pension Systems and Reform”, The World Bank, https://doi.org/10.1596/o-8213-6o4o-X

Jensen, S., Pedersen, T., Foxman T, (2019). "Experiences with Occupational Pensions in Denmark", Quarterly Journal of Economic Research, DIW Berlin, German Institute for Economic Research, vol. 88(1), pages 11-30.

Kay, S. J. (2014). "Political Risk and Pension Reform in Latin America and Central and Eastern Europe". Documento elaborado para la reunión de la ISA/FLACSO, Buenos Aires.

Kuitto K. \& Kuivalainen, S. (2020). Pension, In the Handbook on Society and Social Policy, pp $279-290$. https://doi.org/10.4337/9781788113526.00029

Mabbett, D. (2020). Reckless Prudence: Financialisation in UK Pension Scheme Governance after the Crisis. Review of International Political Economy. https://doi.org/10.108o/o9692290.2020.1758187.

Mesa-Lago, C., Bertranou, F., (2016), "Pension Reform in Chile and Social Security Principles 1981-2015", International Social Security Review, Volume 69, Issue 1, pp. 25-45.

Mesa-Lago, C. \& Valero, D. (2020). "The New Wave of Pension Reforms in Latin America". In: Peris-Ortiz M., Álvarez-García J., Domínguez-Fabián I., Devolder P. (eds) Economic Challenges of Pension Systems. Springer, Cham. https://doi.org/10.1007/978-3-030-37912-4_12

Naczyk, M., Domonkos, S., (2016), “The Financial Crisis and Varieties of Pension Privatization Reversals in Eastern Europe", Governance, Volume 29, Issue 3, pp.167-184.

Natali, D., (2018), "Recasting Pensions in Europe: Policy Challenges and Political Strategies to Pass Reforms", Swiss Political Science Review, Vol 24 Issue 1, pp 53-59.

Nelson, K., Nieuwenhuis, R., Alm, S., (2019), "Sweden: Adjoining the Guarantee Pension with NDC", Social Protection Discussion Papers and Notes from The World Bank

OECD (2019), Pensions at a Glance 2019: OECD and G2o Indicators, OECD Publishing, Paris, https://doi.org/10.1787/b6dzdcfc-en.

Orenstein M. A., (2013), "Pension Privatization: Evolution of a Paradigm", Governance, Volume 26, Issue 2, pp. 259-281.

Pennacchi, GG , (1999), “The value of guarantees on pension fund returns”, Journal of Risk and Insurance, vol. 66, no. 2, pp. 219-237. https://doi.org/10.2307/253610.

Rappaport, A. M. \& Peterson, A. (2014). "Risk-sharing Alternatives for Pension Plan Design: An Overview and Case Studies". Wharton Pension Research Council Working Papers. 92. https://repository.upenn.edu/prc_papers/92

Smetters., K., (2002) “Controlling the cost of minimum benefit guarantees in public pension conversions”, Journal of Pension Economics and Finance, Cambridge University Press, 1(1), pp. 9-33. doi: 10.1017/S1474747202001014.

Sokhey, S. W. (2017). The Political Economy of Pension Policy Reversal in Post-Communist Countries. Cambridge University Press

Wolf, I, Caridad y Lopez del Rio, L. (2021a), "Funded-capitalized pension designs and the demand for minimum pension guarantee" Public and Municipal Finance, 10(1), 12-24. doi:10.21511/pmf.10(1).2021.02

Wolf, I., Caridad y Lopez Del Rio, L., (2021b). "Pension Reforms and Risk Sharing Cycle: A Theory and Global Experience," International Journal of Economics \& Business Administration (IJEBA), vol. 9(1), pages 225 -242. 
Wolf, I., Caridad Lopez del Rio, L., (2021c). "Benefit Adequacy in Funded Pension Systems: Micro-Simulation of the Israeli Pension scheme." International Journal of Economics \& Business Administration, vol. 9(2), pages 143-164. http://doi.10.10.35808/ijeba/694

Wolf, I., Ocerin, J.C.M. (2021). " The transition to a multi-pillar pension system: the inherent socio-economic anomaly". Journal of Financial Economic Policy,. ahead-of- print. https://doi.org/10.1108/JFEP-07-2020-0162

World Bank, 1994, "Averting the old age crisis: Policies to protect the old and support growth", New York, NY, Oxford University Press.

\section{Appendix 1:}

\begin{tabular}{|c|c|c|c|c|}
\hline \multicolumn{2}{|r|}{ Country } & Reform & Reversal & Influence on Benefit Adequacy and Insurance \\
\hline \multicolumn{5}{|c|}{ CEE Countries } \\
\hline 1 & Bulgaria & 2002 & 2007 & $\begin{array}{l}\text { Funded pillar with } 5 \% \text { contribution rate. } \\
2014 \text { - Minimum income support for the elderly is provided through the } \\
\text { state; } \\
\text { The minimum old-age pension amount is set every year by the Public } \\
\text { Social Insurance Budget Law; }\end{array}$ \\
\hline 2 & Croatia & 1999 & 2011 & $\begin{array}{l}\text { Retrenchments of private second pillar mandatory pensions; } \\
\text { Mandatory individual account contribution reduced from } 10 \text { per cent to } \\
5 \text { per cent }\end{array}$ \\
\hline 3 & Czechia & 2004 & $\begin{array}{l}2016 \text { - Terminating } \\
\text { individuals' accounts }\end{array}$ & $\begin{array}{l}\text { Pension fund managers must guarantee the nominal value of } \\
\text { contribution made by plan members every year. } \\
\text { Contributions cannot receive a negative rate of return; }\end{array}$ \\
\hline 4 & Estonia & 2002 & 2009 & $\begin{array}{l}\text { The government suspend its contribution to the second pillar; } \\
\text { Universal benefit component as part of the first pillar; }\end{array}$ \\
\hline 5 & Hungary & 1998 & $\begin{array}{l}2011 \text { - Terminating } \\
\text { individuals' accounts }\end{array}$ & $\begin{array}{l}\text { Minimum pensnion guarantee finances from the state budget; } \\
\text { Mandatory pension funds must ensure that the investments return is } \\
\text { not less than } 15 \% \text { less than the yield on Hungarian government bonds; } \\
\text { pension-tested benefit around } 103 \text { USD per month (2018) and } 80 \\
\text { USD means-tested (2013); }\end{array}$ \\
\hline 6 & Kazakhstan & 1998 & 2004 & $\begin{array}{l}2013 \text { - Reversal of privatization and intriduction of 0 Pillar: Basic } \\
\text { Social Pension (BPP) (unconditional, universal pension payment). } \\
\text { The zero pillar consists of the basic social pension (BSP). All citizens } \\
\text { who have reached retirement age receive a BSP. The BSP is an } \\
\text { equal amount for all, regardless of work experience and salaries. } \\
2018 \text { - minimum pension of } 45 \$ \text {, corresponding to } 54 \text { per cent of the } \\
\text { minimum subsistence level (MSL). Since } 1 \text { July } 2018 \text {, the BSP also } \\
\text { increases with years of employment, for a maximum of } 100 \text { per cent } \\
\text { of the MSL; }\end{array}$ \\
\hline 7 & Latvia & 2001 & 2009 & $\begin{array}{l}2014 \text { - minimum income level of } 40 \% \text { of the median income } 71-109 \\
\text { EUR depends in contribution period; } \\
2017 \text { - basic pension guarantee of } 64 \text { EUR a month; }\end{array}$ \\
\hline 8 & Lithuania & 2004 & $\begin{array}{l}2009-2019 \\
\text { Downsizing of ondividual } \\
\text { accounts; }\end{array}$ & Insurance as part of the point system by contributions; \\
\hline 9 & Macedonia & 2006 & 2011 & $\begin{array}{l}\text { Contributions to mandatory individual accounts reduced from } 7.42 \text { per } \\
\text { cent to } 5.25 \text { per cent and strengthening the first pillar. }\end{array}$ \\
\hline 10 & Poland & 1999 & $\begin{array}{l}2014,2017 \\
2014 \text { - Terminating } \\
\text { indivudal accounts and } \\
\text { transfer to ZUS; }\end{array}$ & $\begin{array}{l}\text { Pension funds must ensure that returns fall within a band that is } \\
\text { defined as the greatest of } 4 \text { percent points below the weighted- } \\
\text { average real rate of return over the previous } 12 \text { months and } 50 \% \text { of } \\
\text { the weighted-average return; } \\
\text { Available for men } 65+\text { and for women } 60+\text {. In addition, a means and } \\
\text { pension-tested benefit is provided; } \\
\text { Financed from public funds; }\end{array}$ \\
\hline 11 & Romania & 2004 & $\begin{array}{l}2009-2017 \\
2017 \text { - government } \\
\text { reduced and froze } \\
\text { contribution } \\
\text { rates to } 2 \text { nd individual } \\
\text { account pillar. } \\
\end{array}$ & $\begin{array}{l}2012 \text {-a guarantee fund to protect the second and the third pillar } \\
\text { savings was created; }\end{array}$ \\
\hline 12 & $\begin{array}{l}\text { Ruusia } \\
\text { Federation }\end{array}$ & 2002 & 2012 & Contributions to individual accounts are diverted to social insurance \\
\hline 13 & Slovakia & 2005 & $\begin{array}{l}2008-2015 \\
\text { Downsizing of individual } \\
\text { accounts. }\end{array}$ & $\begin{array}{l}2013 \text { - Contribution rates were reduced from } 9 \% \text { to } 4 \% \text {, since } 2017 \\
\text { increase by } 0.25 \% \text { up to } 6 \% \text { in } 2024 \text {; } \\
2009 \text { - Pension fund management companies are required to } \\
\text { guarantee a zero percent rate of return every six months; }\end{array}$ \\
\hline
\end{tabular}




\begin{tabular}{|c|c|c|c|c|}
\hline \multicolumn{2}{|c|}{ Country } & Reform & Reversal & Influence on Benefit Adequacy and Insurance \\
\hline \multicolumn{5}{|c|}{ Latin America Countries } \\
\hline 1 & Argentina & 1994 & $\begin{array}{l}\text { Government ends } \\
\text { individual accounts and } \\
\text { transfers funds to PAYG } \\
\text { system }\end{array}$ & $\begin{array}{l}\text { Non-contributory universal and basic pension-tested benefit to person } \\
\text { aged } 65+\text { not receiving any other pension corresponding to } 80 \% \text { of } \\
\text { the minimumPAYG pension; } \\
\text { Extended by 'Moratorium' program - alowed workers of retirement } \\
\text { age to receive a pension regardless of whether they had completed } \\
\text { the full } 30 \text { years of required social security contributions through } \\
\text { formal employment, } \\
\text { Means-tested benefit is provided to person aged } 70+\text { without any } \\
\text { other income corresponding to } 70 \% \text { of the minimumPAYG pension, }\end{array}$ \\
\hline 2 & Unuguay & 1996 & & $\begin{array}{l}\text { Complementary pension scheme where the pay-as-you-go system } \\
\text { provides a universal benefit, but workers with higher income are } \\
\text { required to contribute to the individual capitalization system. }\end{array}$ \\
\hline 3 & Mexico & 1997 & & $\begin{array}{l}2009 \text { - Guararteed minimum pension equal in the social security } \\
\text { pillar to "one minimum wage" for those who have contributed } \\
\text { long enough to qualify. }\end{array}$ \\
\hline 4 & Bolivia & 1996 & $\begin{array}{c}2009 \\
\text { Closing indiviual accounts } \\
\text { system. }\end{array}$ & $\begin{array}{l}\text { Non-contributory Zero pillar, 'Renta Dignidad' is granted to al the } \\
\text { population aged } 60+\text { from stste budget, } \\
2010 \text { - Solidarity pension - minimum pension scheme which provide } \\
\text { income protection for older persons and guarantee replacement rate } \\
\text { of } 70 \% \text { with } 30 \text { years of contribution from the age of } 60 \text {; } \\
\text { Financed by contributions of workers }(0.5 \%-10 \%) \text { and the employer } \\
(3 \%) \text {; }\end{array}$ \\
\hline 5 & Chile & 1981 & & $\begin{array}{l}2008 \text { - Launching a zero pillar solidarity supplement that integrated } \\
\text { with the existing funded pillar and serves as pension supplement to } \\
\text { pensioners in the lowest } 60 \text { percent of the income distribution. This } \\
\text { reformis seen as a benchmark; } \\
2018 \text { - President Pinera announced that he would undertake a } \\
\text { pension reform to increase the solidarity pillar and to create a special } \\
\text { benefit supplement for women and the middle-class who are near or } \\
\text { past retirement age: }\end{array}$ \\
\hline 6 & Colombia & 1994 & & $\begin{array}{l}2003 \text { - Fondo de Solidaridad Pensional - to subsidize pension } \\
\text { contributions of workers with low earning; } \\
2013 \text { - The labor ministry announced a proposed pension reform bill } \\
\text { aimed at reducing inequality and poverty and ensuning financial } \\
\text { sustainability. }\end{array}$ \\
\hline 7 & Costa Rica & 2001 & & $\begin{array}{l}\text { adopted private individual retirement savings as a complement to the } \\
\text { defined benefit public system } \\
\text { Include a minimumpension guarantee with large coverage by means } \\
\text { tested. }\end{array}$ \\
\hline 8 & Ecuador & 2001 & 2002 & $\begin{array}{l}\text { Foundation of the 'Fondo Solidario' - Semi-contributory scheme for } \\
\text { low pension levels; }\end{array}$ \\
\hline 9 & EI Savador & 1998 & 2017 & $\begin{array}{l}\text { Solidarity Guarantee Account, aimed at paying a guaranteed } \\
\text { minimum supplementary pension, } \\
\text { Financed by increasing conteribution rates from } 13 \% \text { to } 15 \% \text { and } \\
\text { channeling } 2 \text { percentage points to finance; }\end{array}$ \\
\hline 10 & Nicaragua & 2000 & $\begin{array}{l}2005 \\
\text { Terminating individual } \\
\text { accourts }\end{array}$ & Declaring private pensions unconstitutional \\
\hline 11 & Venezuela & 1997 & $\begin{array}{l}2000 \\
\text { Terminating individual } \\
\text { accounts }\end{array}$ & $\begin{array}{l}2002 \text { - New Social Security Framework Law: Average-premium } \\
\text { public and solidarity programme. Defined benefit and public } \\
\text { administration. Decision to standardize retirement programmes and } \\
\text { establish new } \\
\text { institutions. }\end{array}$ \\
\hline \multicolumn{5}{|r|}{ Other OECD Countries } \\
\hline 1 & Aus tralia & 1992 & & $\begin{array}{l}\text { FDC with three pension pillars. } \\
\text { The first pillar includes Minimum pension guarantee of } 27.8 \% \text { from } \\
\text { average wage indexed to the cost of living. The coverage is means- } \\
\text { tested against income and assets. } \\
\text { Financed from the state budget. }\end{array}$ \\
\hline 2 & Denmark & 1994 & & $\begin{array}{l}\text { Public pilar and FDC. The FDC is one of the big in the OECD in } \\
\text { assets and coverage. } \\
\text { Minimum pension guarantee of } 2800 \text { S a month, compares to both } \\
\text { pillars and depends on citizenships. }\end{array}$ \\
\hline 3 & Norway & 2011 & & $\begin{array}{l}\text { NDC+Supplementary funded pensions. } \\
\text { The minimum pension has not been changed duning the reform - } 33 \% \\
\text { of average wage, exempt fromtaxes. } \\
\text { The guaranteed pension will be income tested by } 80 \text { percent of the } \\
\text { income pension. In other words, people with a low income pension } \\
\text { Who receive a guaranteed pension will keep } 20 \text { percent of their } \\
\text { income pension and will thus receive a total pension above the } \\
\text { minimum level. }\end{array}$ \\
\hline 4 & Sweden & 1994 & & $\begin{array}{l}\text { Mix pension system of NDC and small pillar of FDC. } \\
\text { Implemenytation of minimumpension guarantee and housing from the } \\
\text { state budget and is being indexed. } \\
\text { The parliamentary revew group on the Swedish pension system } \\
\text { (Pensionsgruppen) recently suggested several reforms to improve the } \\
\text { lowest pensions, including increases in the Sweden guaranteed } \\
\text { minimum pension and in housing supplements (Social Ministry 2018) }\end{array}$ \\
\hline
\end{tabular}

Source: Author's elaboration based on Kay (2014), Naczys and Domonkos (2016), Priceand \& Rudolph (2013) and the OECD report 2019. 